Institute of $\mathbf{F}_{\text {ood and }} \mathbf{A}_{\text {gricultural }} \mathbf{S}_{\text {ciences }}$

\title{
Rove Beetles of Florida, Staphylinidae (Insecta: Coleoptera: Staphylinidae) ${ }^{1}$
}

\author{
J. H. Frank and M. C. Thomas ${ }^{2}$
}

\section{Introduction}

Rove beetles are often abundant in habitats with large numbers of fly larvae -- especially decaying fruit, decaying seaweed, compost, carrion, and dung -- where some are important predators of maggots and others prey on mites or nematodes. Because they are abundant in decaying plants and fruits, plant inspectors encounter them but often do not recognize them as beetles. This article is intended as an introduction to the Florida representatives of this large, diverse, and important family of beetles. Characterization here is to the level of subfamily (at least 17 subfamilies occur in Florida) because characterization to the level of genus (or species) would be too complicated for a publication of this kind. The best popular North American identification guide to beetles (White 1983), likewise characterizes Staphylinidae only to the level of subfamily (and its classification is outdated, and it does not provide references to the literature).

\section{Description}

Most rove beetle adults are slender with short elytra; when of this typical form, the body shape ranges from cylindrical (genus Osorius) to much flatter, and the abdomen is very muscular and flexible. In some (Micropeplinae and Pselaphinae) the abdomen is less flexible, and in a few (Scaphidiinae) the body form is much broader and the elytra almost cover the abdomen. In most, the antennae are simple and typically have 11 antennomeres ("segments"), but in some (Pselaphinae) the antennae are clubbed or (Micropeplinae) have a greatly enlarged apical segment, or (some Aleocharinae) have 10 or (some Pselaphinae) even fewer antennomeres. Antennae are geniculate ("elbowed") in a few members of Pselaphinae, Osoriinae, Oxytelinae, Paederinae, and Staphylininae.

Adults range from less than $1 \mathrm{~mm}$ to $40 \mathrm{~mm}$ long (none is more than about $20 \mathrm{~mm}$ in Florida), although almost all are less than about $7 \mathrm{~mm}$ long. Adults of some other families also have short elytra, but in these (e.g., various Histeridae; Limulodes and other

1. This document is EENY-115 (originally published as DPI Entomology Circular No. 343), one of a series of Featured Creatures from the Entomology and Nematology Department, Florida Cooperative Extension Service, Institute of Food and Agricultural Sciences, University of Florida. Published: October 1999. Revised: December 2002. This document is also available on Featured Creatures Website at http://creatures.ifas.ufl.edu. Please visit the EDIS Website at http://edis.ifas.ufl.edu. Additional information on these organisms, including many color photographs, is available at the Entomology and Nematology Department website at http://entnemdept.ifas.ufl.edu/.

2. J. H. Frank, professor, Entomology and Nematology Department, University of Florida, Gainesville, FL, and Michael C. Thomas, Florida Department of Agriculture and Consumer Services, Division of Plant Industry, Gainesville, FL.

The Institute of Food and Agricultural Sciences is an equal opportunity/affirmative action employer authorized to provide research, educational information and other services only to individuals and institutions that function without regard to race, color, sex, age, handicap, or national origin. For information on obtaining other extension publications, contact your county Cooperative Extension Service office. Florida Cooperative Extension Service/Institute of Food and Agricultural Sciences/University of Florida/Christine Taylor Waddill, Dean. 
Ptiliidae; Nicrophorus, family Silphidae; Trypherus, family Cantharidae; Conotelus, family Nitidulidae; Rhipidius, family Rhipiphoridae; Meloe, family Meloidae; and Inopeplus, family Salpingidae) the abdomen has little flexibility, the elytra are not rectangular, the antennae are strongly clubbed at the apex or otherwise modified and the wing-venation and folding mechanisms differ. As defined here, following Lawrence \& Newton (1995), the family includes Micropeplinae, Pselaphinae, and Scaphidiinae (earlier treated as separate families).

Earwigs (Order Dermaptera) are often confused by non-entomologists with rove beetles, but have moveable forceps at the end of the abdomen, many-segmented antennae, a radial wing-folding mechanism, and numerous other differences.

Eggs of Staphylinidae typically are white, spherical, spheroidal, or pyriform (pear-shaped). Almost all larvae are elongate and campodeiform, their antennae with three or four articles, with a sensory appendage on the penultimate article and typically facing anteriorly, the abdominal apex with urogomphi typically present and articulated, each leg with a claw-like tarsungulus. Pupae of most Staphylinidae are white and exarate, but those of Staphylininae are obtect, pigmented and sclerotized (Frank 1991; Newton 1991).

\section{Life Cycle and Habits}

Probably more than 600 species occur in Florida, though only slightly under 500 are now recorded (Frank 1986; Lundgren 1998). Habits and appearance vary widely in this large family. Only for the small subfamilies Micropeplinae, Oxyporinae and Leptotyphlinae and the larger subfamily Tachyporinae are there comprehensive modern taxonomic works allowing identification of all known Florida adults to the species level. Only for a few Florida species are there accounts of behavior of adults or descriptions of immature stages, due almost entirely to studies in other parts of their range, for which reason the study of Staphylinidae is a fertile field. There are no accounts of population dynamics (bionomics).

Adults of most species are nocturnal, or at least hide from light during daylight hours, and are confined to moist microhabitats; some exceptions are Stenus and Paederus which are active in daylight. Adults and larvae of most species are facultative predators, but some are specialist predators, some are mycophagous or saprophagous or even phytophagous, occasionally damaging flowers and turf. Larvae of Aleochara are parasitoids of dipterous pupae. Several species, especially of Aleocharinae, are obligate inquilines of nests of social insects (ants and termites). Larvae of Stenus, Astenus, and many species of Aleocharinae spin a cocoon before pupating. In general, adults are long-lived, with eggs, larvae and pupae developing in a few days to a few weeks. The few Florida species for which life cycle information is known, albeit unpublished, breed throughout the year, which is more typical of tropical than of temperate species.

Staphylinids can be found in most moist habitats, especially where there is decaying plant or animal material. They can be extracted in numbers from soil and leaf litter by Berlese funnel. Adults of some species are often abundant at light or in ultraviolet trap samples.

\section{Subfamilies in Florida}

\section{Proteininae}

Typical adults are 1.5-3 mm long, somewhat broader in shape than are most Staphylinidae, with somewhat long elytra, the head with a broad neck, the antennae of 11 articles (nine through 11 or eight through 11 broader than those preceding), and tarsi of three, four, or five articles. In some genera the elytra cover the entire abdomen, and in some there is a median ocellus near the base of the head. In larvae, the mandible has a prostheca, and the maxillary mala is very long and slender.

Adults and larvae are saprophagous or mycophagous. They live in fungi and decaying vegetation, and sometimes are found in carrion and in caves. Only one species, Proteinus thomasi Frank, is reported for Florida (Frank 1979) although there are more. 


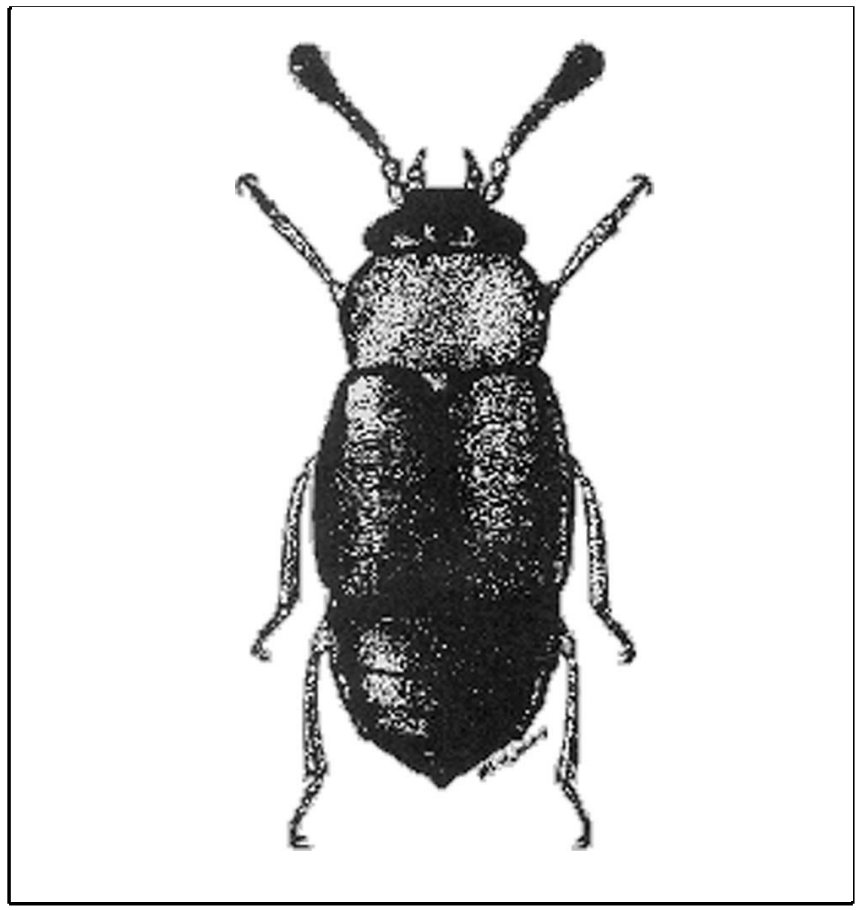

Figure 1. Proteinus thomasi Frank (Proteininae) $1.5 \mathrm{~mm}$. Credits: M. C. Thomas, Division of Plant Industry

\section{Omaliinae}

Typical adults are 1.5-6 mm long, somewhat broader in shape than are most Staphylinidae, with somewhat longer elytra, the head with a broad neck, the antennae of 11 articles which are only slightly broader at the apex, and tarsi of five articles. In almost all genera there is a pair of ocelli near the base of the head, and in a few the elytra cover the entire abdomen. The maxillary mala of larvae is strap-shaped, but not as long as in Proteininae, and the mandible lacks a prostheca.

Adults and larvae occur in leaf litter, decaying fruits, moss, and under bark of dead trees. Adults of several species and larvae of a few occur in flowers. Adults and larvae of many genera and species are believed to be predatory (they will feed on freshly killed small insects), though a few seem to be phytophagous (they damage flowers) or saprophagous (they will feed on decaying fruits). Six species are reported for Florida, a number far lower than in the Pacific northwest of the USA

\section{Micropeplinae}

Typical adults are 1-3 mm long, ovoidal and somewhat flattened, the antennae of nine articles of

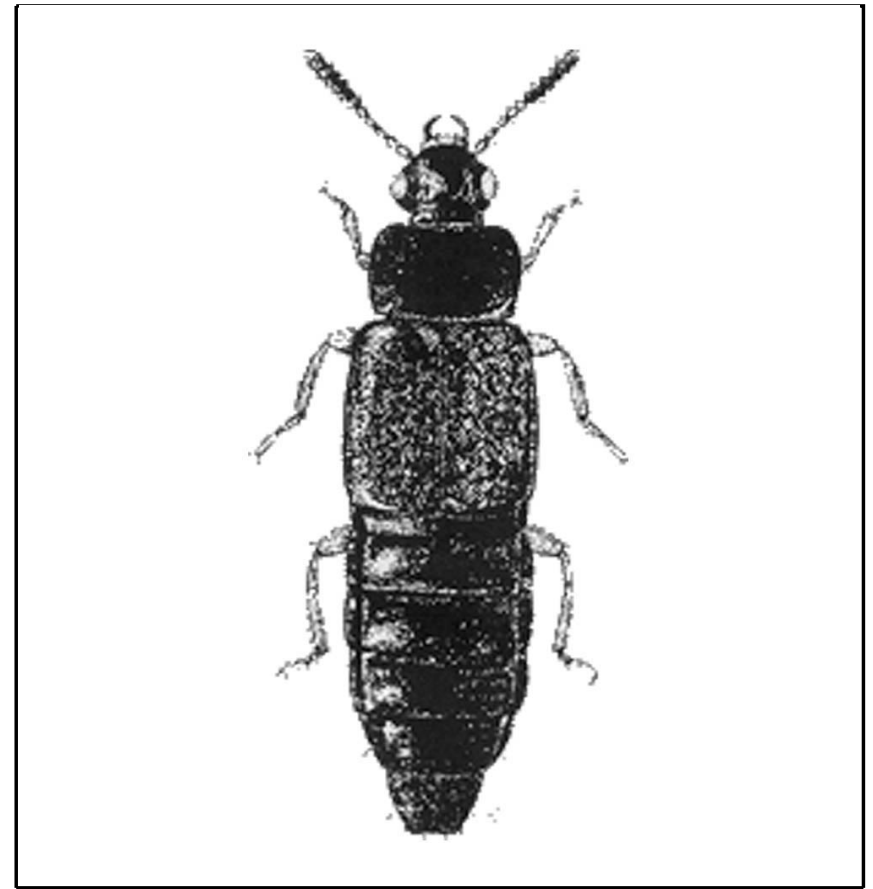

Figure 2. Omalium sp. (Omaliinae) $3.5 \mathrm{~mm}$. Credits: M. C. Thomas, Division of Plant Industry

which the last is much broader than the others (giving the appearance of a club), the tarsi of four articles (though the first is very small and difficult to see), and the body (head, pronotum, elytra and abdominal tergites) has strong ridges. Larvae are exceptionally well-sclerotized, even the abdomen having sclerotized plates, and these abdominal plates project laterally from the body.

Adults and larvae occur in leaf litter and associated with fungus-infested dead trees. Their food has not been investigated. At least one species occurs in Florida, though none has yet been reported in print (Campbell 1968).

\section{Pselaphinae}

Adults are 0.5-5.5 mm long. Unlike other staphylinids, they have clubbed antennae and, unlike most others, have a relatively inflexible abdomen. The head, thorax, and elytra have foveae in a typical pattern. The antennae arise from under frontal protrusions. Larvae with urogomphi short and fixed (not articulated) or absent; typically with two stemmata (elsewhere called ocelli) on each side of head.

Adults and larvae live among leaf litter on the soil surface, or under bark of fallen trees. They are 


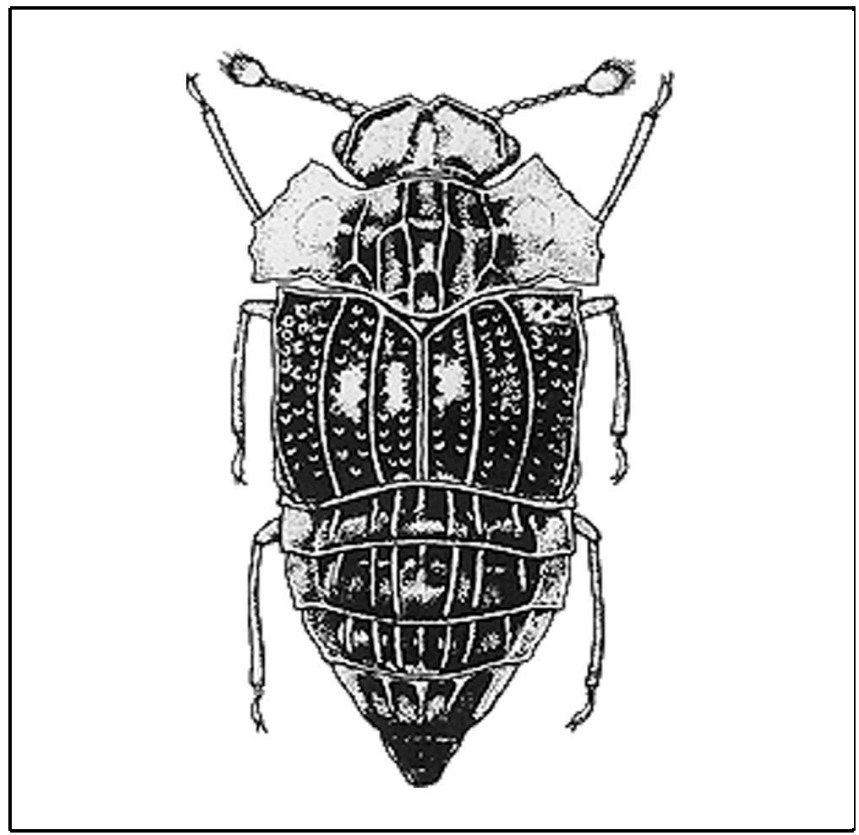

Figure 3. Peplomicrus sp. (Micropeplinae) $2.0 \mathrm{~mm}$. Credits: J. M. Campbell, J. Steins, and Agriculture Canada

predators (despite earlier erroneous accounts). One hundred and two species are reported from Florida (Chandler 1997).

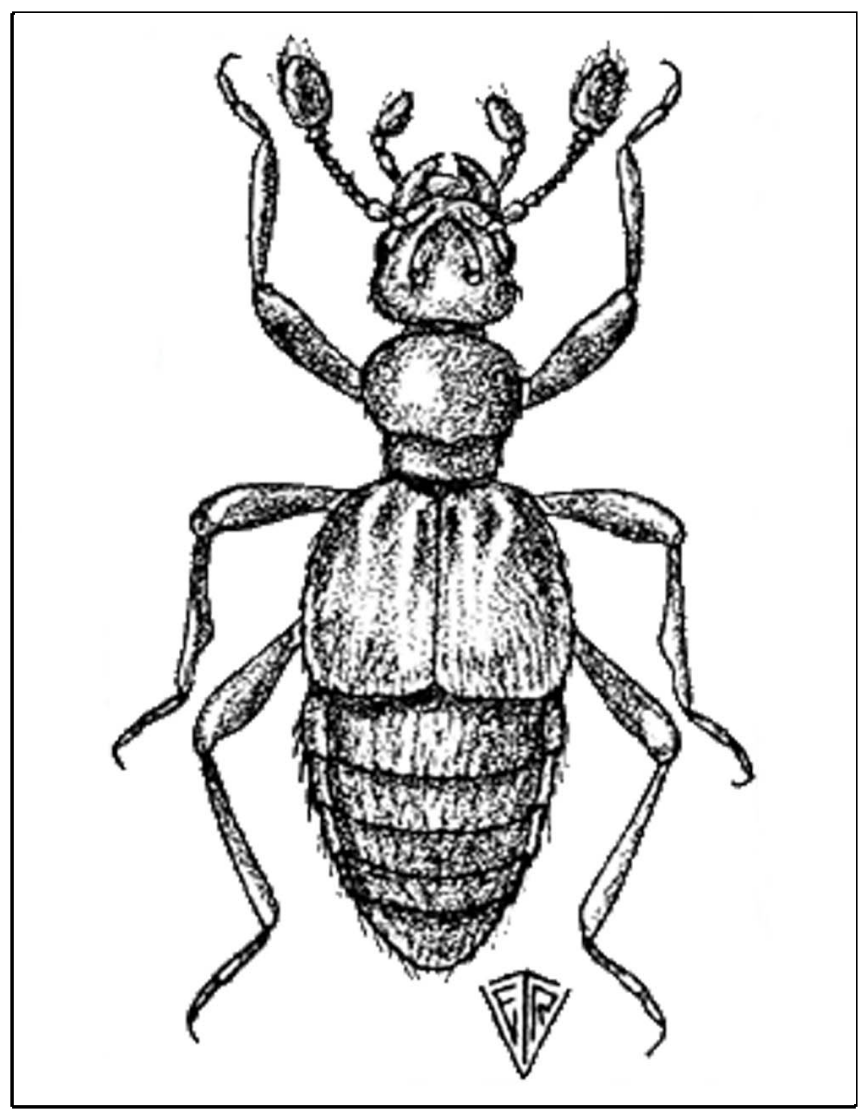

Figure 4. Trimiomelba dubia (LeConte). Credits: E. R. Van Tassell, Michigan State University

\section{Tachyporinae}

Adults are 1.5-6 mm long, the head narrower than the thorax and the abdomen tapering strongly ("torpedo-shaped"), many of them glossy, some of them with bright patterns of yellow on a darker background of brown or black, the antennae of 11 articles which are elongate or with the apical articles slightly broader than the basal articles, the tarsi with five articles. Larvae with urogomphi of two articulated articles.

Adults and larvae occur in various moist habitats such as leaf litter, decaying vegetation and fruits, under bark of fallen trees, and in mushrooms. Adults and larvae are fast-moving and most are generalist predators, though some are mycophagous. Twenty-three species have so far been reported for Florida (Campbell 1975, 1976, 1979, 1991, 1993).

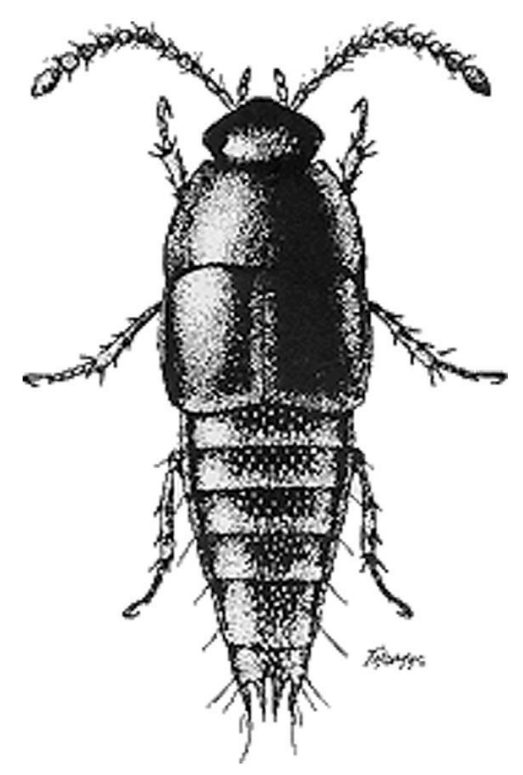

Figure 5. Coproporus rutilus (Erichson) (Tachyporinae) $3.8 \mathrm{~mm}$. Credits: M. C. Thomas, Division of Plant Industry

\section{Aleocharinae}

Adults are 1-9 mm long, with short elytra, the antennae inserted into the vertex of the head between the eyes (this characteristic shared only with Steninae), seldom colored brightly, but the abdomen in several with tubercles, ridges and spines, antennae of almost all with 11 articles (in a few, 10) which are simple or broadened toward the apex, tarsi of three, four or five articles. Larvae have a single stemma (or 
no stemmata) on each side of the head whereas larvae of most other known Staphylinidae have either none or at least two.

The species of this enormous subfamily occupy almost every conceivable moist habitat. Some inhabit the nests of termites and ants. Adults of some of these resemble their hosts and have behavior enabling them to interact with the social insects, others inhabit the nests of birds and small mammals, while yet others inhabit guano in caves, the dung of epigean vertebrates, decaying fruits, the leaves of living plants, mushrooms, carrion, and the shores of lakes, rivers and the sea. The larvae of Aleochara are internal parasitoids of dipterous pupae. Most are generalist predators, but some are specialists and a few are not predatory but mycophagous with subsocial behavior (Ashe 1987). One hundred and three species are reported for Florida (Ashe 1986; Frank \& Thomas 1981, 1984b, 1997; Génier 1989; Hoebeke 1985; Klimaszewski and Peck 1986; Klimaszewski et al. 1990; Newton 1988; Seevers 1978), although there are many more.

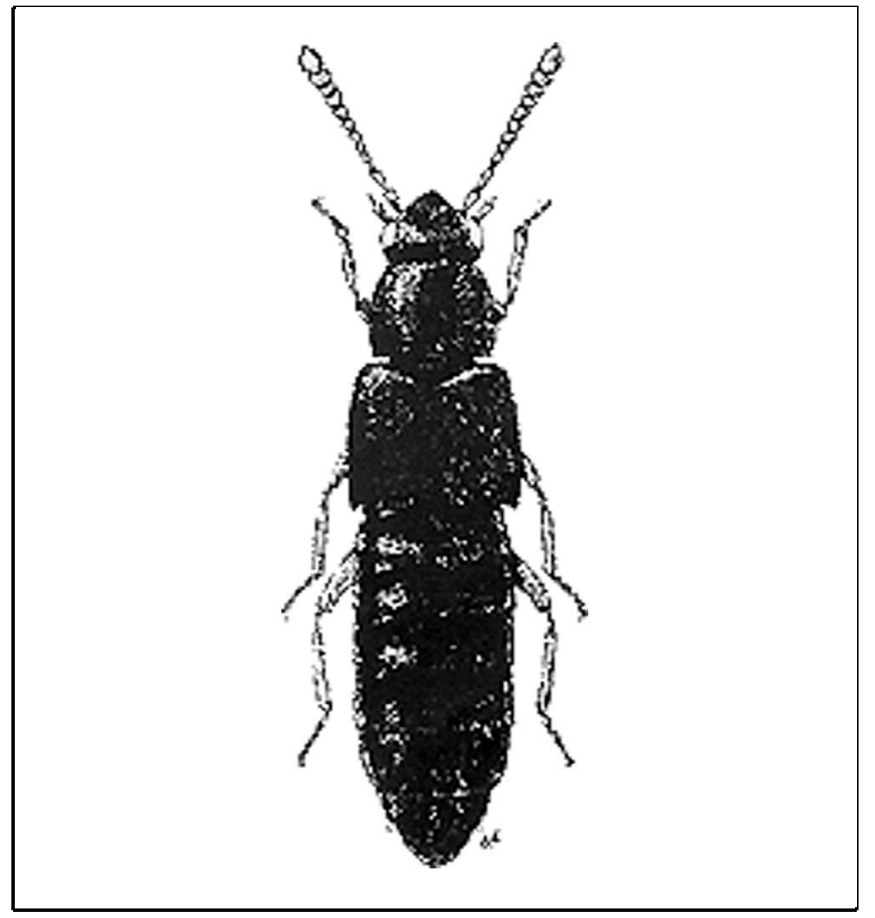

Figure 6. Heterota plumbea Waterhouse (Aleocharinae) $2.8 \mathrm{~mm}$. Credits: M. C. Thomas, Division of Plant Industry

\section{Piestinae}

Adults are 2-7 mm long and flattened, with antennae of 11 articles (the basal ones elongate, the remainder either elongate or quadrate) of which the basal article of the male or of both sexes has a tooth or a tuft of long and coarse setae, and with tarsi of five articles. In the larva, the labial ligula and maxillary mala are broad, and the mandibular apex is divided into three or four points.

Adults and larvae are slow-moving. They live together under the bark of dead trees and in cut banana stems, and probably are saprophagous or mycophagous. The only reported Florida representative is Hypotelus hostilis Fauvel.

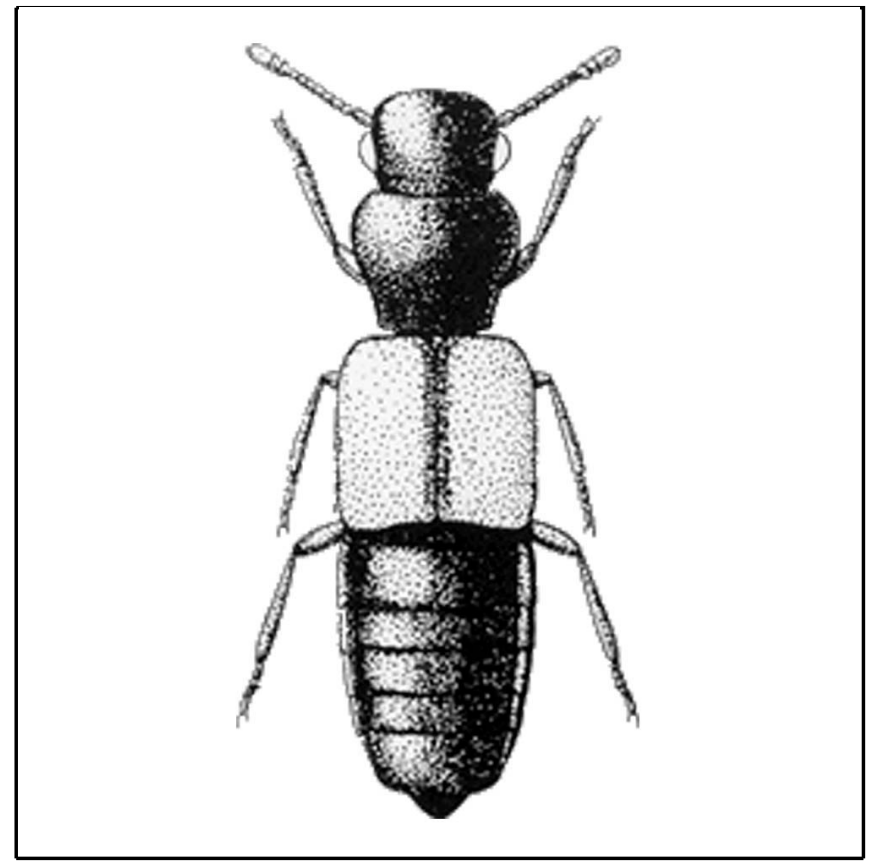

Figure 7. Hypotelus hostilis (Piestinae) 1.9 mm. Credits: M. C. Thomas, Division of Plant Industry

\section{Osoriinae}

Adults are 1.5-15 mm long, elongate, flattened or cylindrical, the sclerites fused in a ring around each abdominal segment; in most genera and species the integument is glossy but in some (e.g., Thoracophorus) it is sculptured and strongly ridged, the antennae of 11 stout articles, the tarsi of five articles. Larvae, too, are flattened or cylindrical and have articulated urogomphi of two articles. 
Adults and larvae are slow-moving. Their typical habitat is under the bark of dead trees and in decaying wood (Bohác 1978), though some dwell among plant roots. Most are saprophagous but some may be mycophagous, and some appear to eat living plant roots (there are reports of damage to roots of turf-grass by a species of Osorius). Ten species are so far reported from Florida, although there are more.

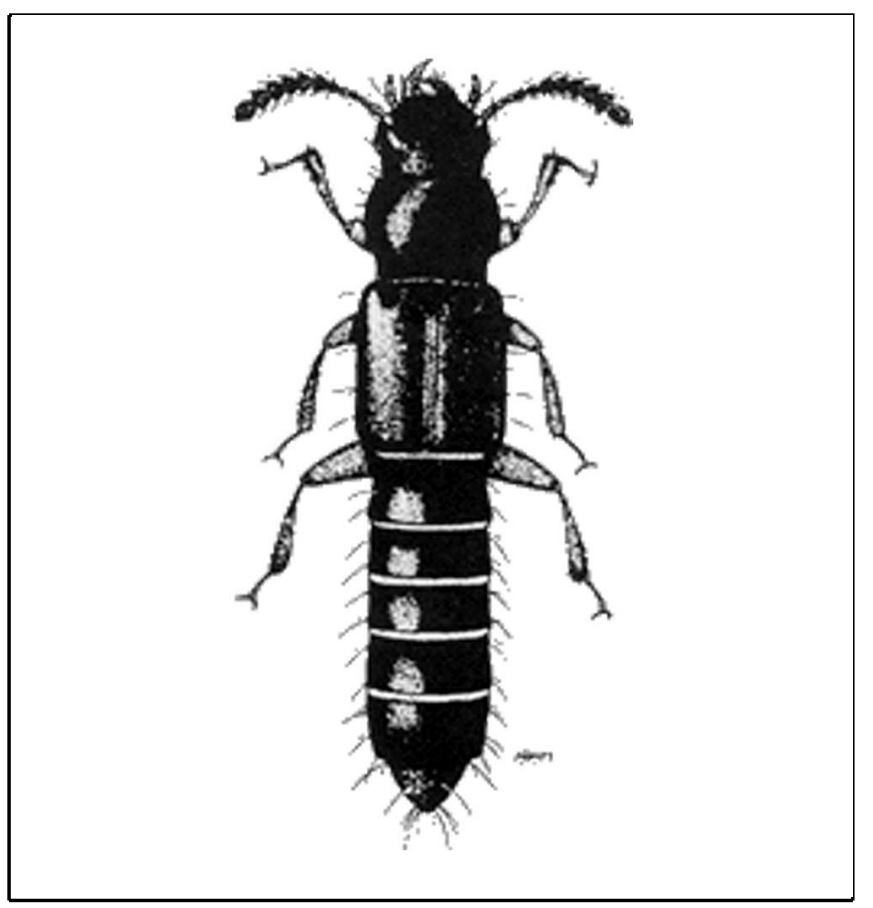

Figure 8. Nacaeus tenellus (Erichson) (Osoriinae) $3.5 \mathrm{~mm}$. Credits: M. C. Thomas, Division of Plant Industry

\section{Oxytelinae}

Adults are $0.5-10 \mathrm{~mm}$ long, few of them glossy, with a well-developed second abdominal sternite (reduced in other subfamilies), the tergite of abdominal segment IX completely divided medially, the antennae with 11 articles either simple in form or the three apical articles forming a loose club, the tarsi with two, three, four or five articles. In the larva, the mandible is divided into three points at the apex, and the urogomphus has one articulated article.

This is another subfamily of Staphylinidae in which subsocial behavior has been recorded, by adults of Platystethus tending the immature stages, and by adults of Bledius maintaining the tunnels inhabited by the eggs (Herman 1986). Adults and larvae are saprophagous, fungivorous or algivorous, with a report of adults of Apocellus damaging flowers
(Chittenden 1915). Although most Staphylinidae are reported to have three larval instars, five have been reported in Bledius. Adults and larvae live among decaying plant materials, in dung of vertebrates, in tunnels which they construct in diatom-laden sandy or muddy shores, or less commonly in nests of vertebrates (Herman 1986, Hu and Frank 1995b). Thirty-six species are reported from Florida, although there are more.

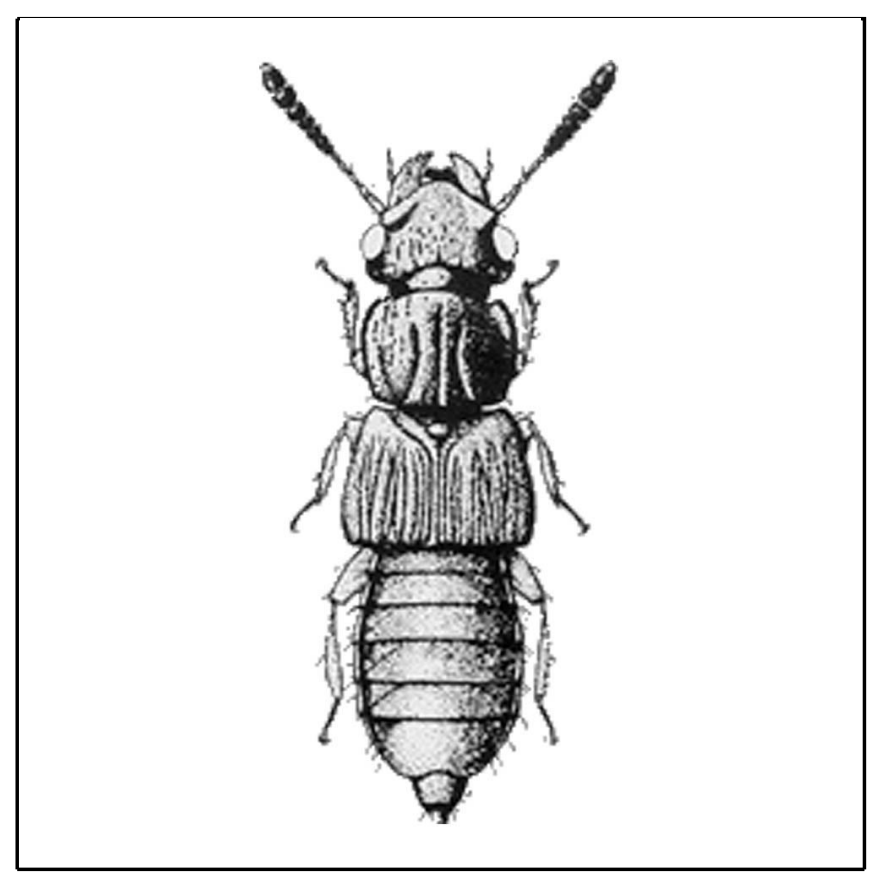

Figure 9. Oxytelus incisus Motschulsky (Oxytelinae) 3.0 $\mathrm{mm}$. Credits: M. C. Thomas, Division of Plant Industry

\section{Scaphidiinae}

Adults are 2-7 mm long, ovoid, convex, glossy and black with long legs, the elytra almost covering the entire abdomen and truncate at the apex, the antennae of 11 articles which are only slightly broader at the apex, each tarsus of five articles. In the larva, the mandible is divided into two points at the apex.

Adults and larvae occur among dead leaves and rotten wood where they are associated with slime molds (Myxomycetes) and other fungi and are believed to be strictly mycophagous (Leschen 1988). Twenty-three species are reported from Florida. 


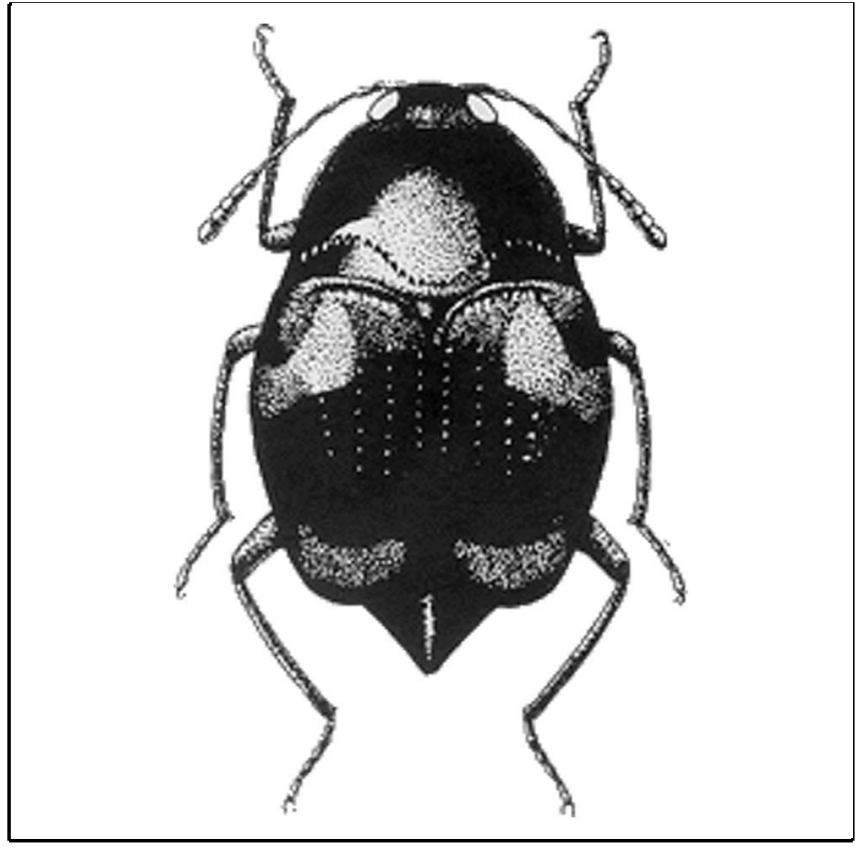

Figure 10. Scaphidium quadriguttatum (Say) (Scaphidiinae) $4.3 \mathrm{~mm}$. Credits: M. C. Thomas, Division of Plant Industry

\section{Oxyporinae}

Adults are 5.5-13.0 mm long, stout, glossy, with long and curved mandibles, with antennae of 11 articles of which articles five through 10 are moderately or strongly transverse, tarsi with five articles. In larvae, the mandible is divided into two points apically, and the maxillary mala is trilobed.

Adults and larvae feed only on fleshy mushrooms, and they digest their food pre-orally as in Steninae, Euaesthetinae, Paederinae and Staphylininae, in contrast with members of subfamilies listed above (Leschen and Allen 1988). Two species are reported for Florida (Campbell 1969).

\section{Megalopsidiinae}

Adults are 3.5-5 mm long, stout, glossy, with very large and prominent eyes, the pronotum transversely grooved, the labrum with two slender projections, the antennae of 11 articles of which articles nine and 10 are transverse and 11 is large (these three together forming a club), antennae fitting into a groove on the anterior and ventral surface of the head, the tarsi of five articles. Larvae have a guillotine-shaped projection near the apex of the

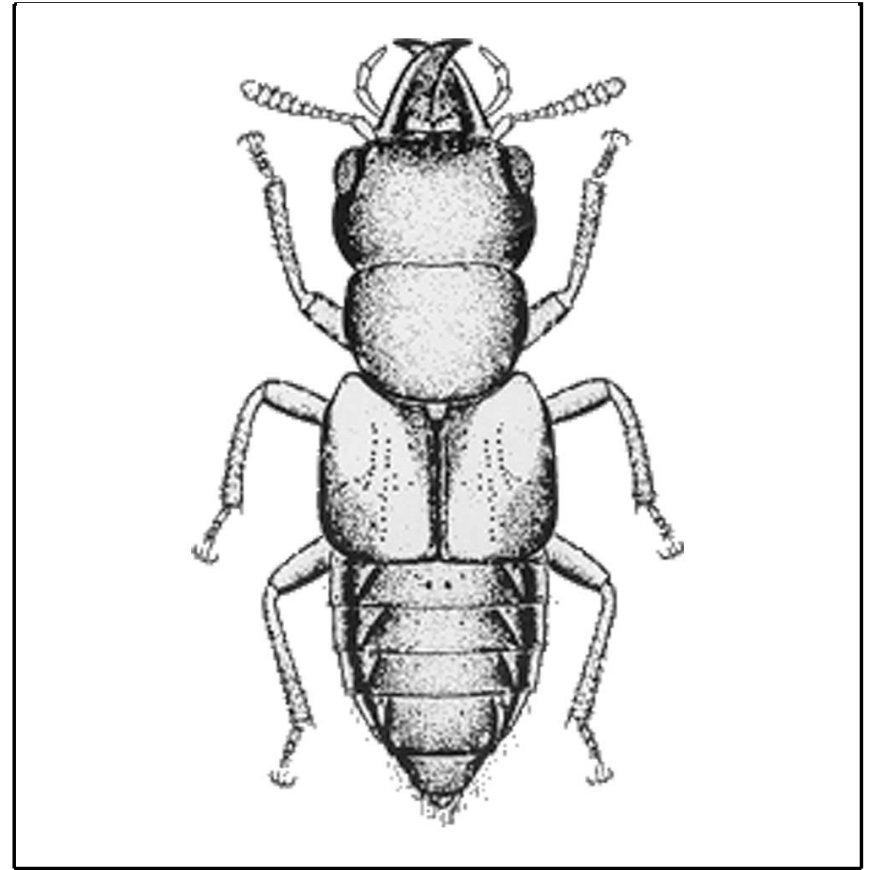

Figure 11. Oxyporus sp. (Oxyporinae) $7.8 \mathrm{~mm}$. Credits: J. M. Campbell, G. Sato, and Agriculture Canada

mandible; their head is scarcely constricted basally and has a subbasal carina.

Not only is there no modern taxonomic revision of any major section of this subfamily, but no studies of the natural history have been published. Adults are associated with fruiting bodies of fungi growing on decaying wood, but are not abundant. Two species are reported for Florida.

\section{Steninae}

Adults are 2-6 mm long, elongate, fairly slender, few of them glossy because of punctation and microsculpture of the body surface, the great majority of them black but a few colored metallically, the legs somewhat long and slender, the eyes large and prominent, the antennae of 11 articles with basal articles slender and apical articles broader to form a loose club, the tarsi with five articles. The large eyes are reminiscent of those of Megalopsidiinae, but Steninae are more slender, less glossy, with more flexible abdomen, and they move faster. The abdomen of adults of some species is margined by paratergites and parasternites as in Paederinae and Staphylininae, but in others the abdominal segments are unmargined and tergites are fused laterally with sternites. The labium of the adult forms a telescopic, prey- catching apparatus, extended by hydraulic 


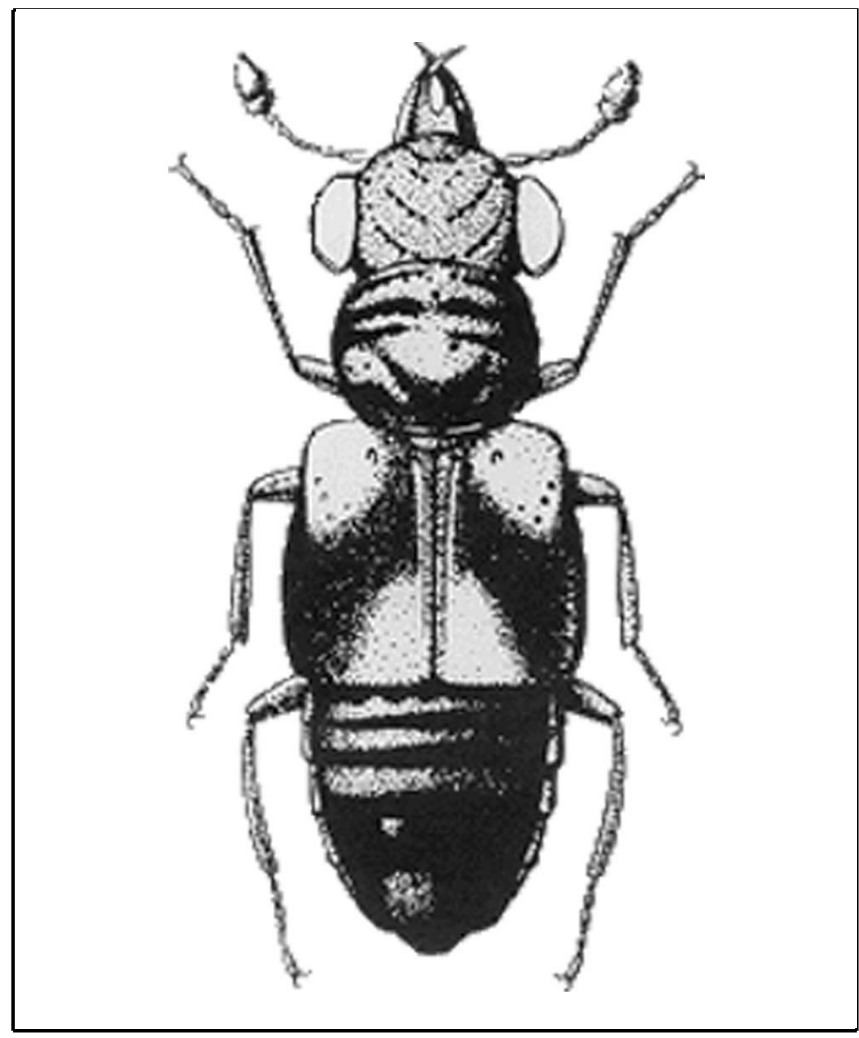

Figure 12. Megalopinus rufipes (LeConte) (Megalopsidiinae) $3.5 \mathrm{~mm}$. Credits: M. C. Thomas, Division of Plant Industry

pressure, whose function is similar to that of the better-known hinged labium of the aquatic nymphs of Odonata. Mandibles of larvae are slender and curved, legs and antennae are long, the ligula of the labium is bilobed, and the head capsule is much better sclerotized than in the subfamilies mentioned above.

Larvae spin silken cocoons in which to pupate. Paired anal glands of the adult secrete a chemical which acts as a surfactant (providing the insect with jet propulsion) on water surfaces: this mechanism seems to be used to regain terra firma when the insects fall onto water surfaces. Adults are active during daylight hours. Some live on banks of bodies of fresh water (lakes, rivers, ditches) and they run on the ground and climb on low vegetation. Others are not restricted to aquatic habitats, and they climb on shrubs. Adults and larvae are predatory on small, soft-bodied insects such as Collembola. (Weinreich 1968). Thirteen species are reported for Florida, although there are more.

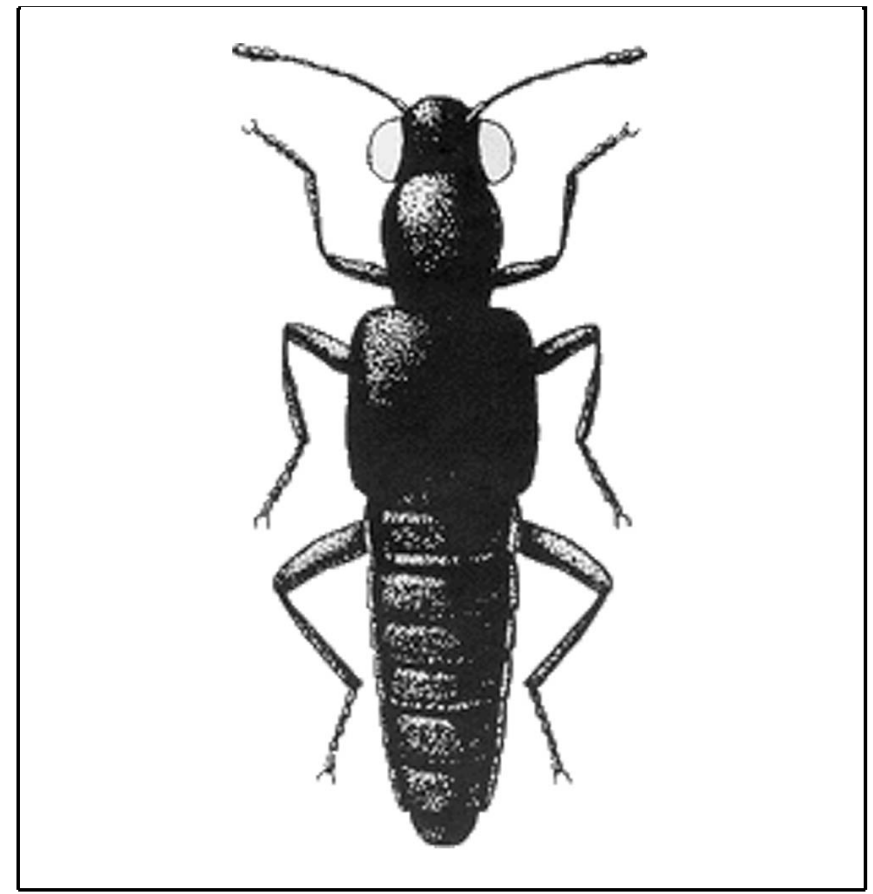

Figure 13. Stenus sp. (Steninae) $4.3 \mathrm{~mm}$. Credits: M. C. Thomas, Division of Plant Industry

\section{Euaesthetinae}

Adults are 1-4 mm long, slender or somewhat stout, yellowish brown or reddish brown, not very glossy, some of them with a feeble metallic lustre, many of them densely punctured, antennae with 11 articles in all species and genera known from Florida and with articles three through eight much shorter than one and two and much narrower than nine through 11 which form an apical club, anterior and middle tarsi each with four or five articles but posterior tarsi in all known species with four. Larvae are similar to those of Steninae but with shorter appendages, and the ligula of the labium is conical.

Adults and larvae live among plant debris on the banks of aquatic habits. Unlike Steninae, the adults do not seem to climb on vegetation. The mouthparts suggest that adults and larvae are predatory, but there are no published studies of natural history. Nine species are so far reported for Florida.

\section{Leptotyphlinae}

Adults are minute, 1-2 mm long, elongate, pale yellowish-brown, soil- inhabiting insects. Only one species, Cubanotyphlus largo Frank, is reported from Florida, known only from the Florida Keys, and its closest relatives inhabit Cuba (Frank and Thomas 


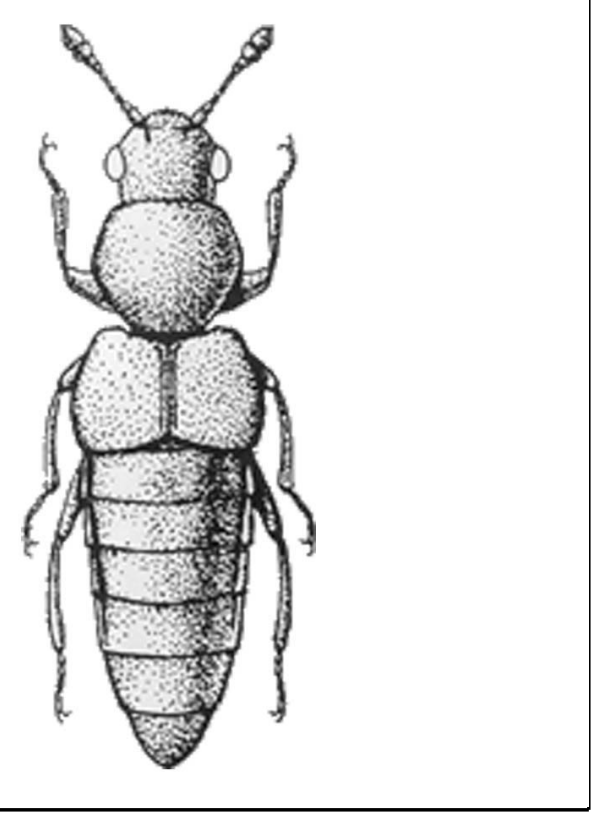

Figure 14. Euaesthetus sp. (Euaesthetinae) $1.4 \mathrm{~mm}$. Credits: M. C. Thomas, Division of Plant Industry

1984a). Adults are eyeless and wingless with undescribed behavior. Larvae are minute, without stemmata, and with urogomphi not or indistinctly articulated.

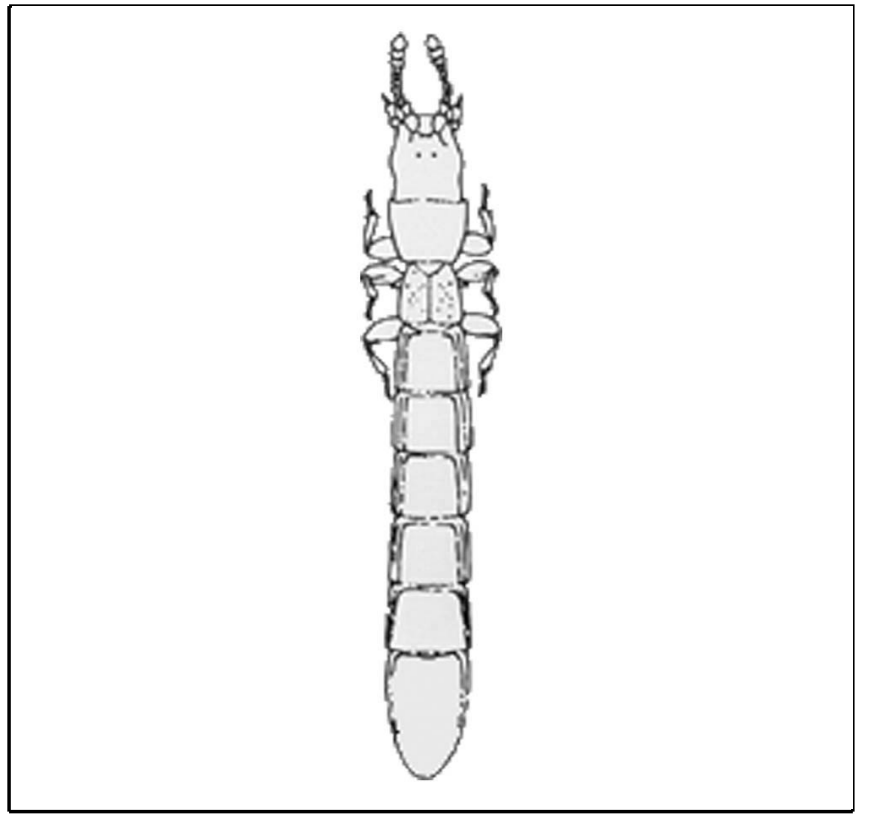

Figure 15. Cubanotyphlus largo (Leptotyphlinae) $1.1 \mathrm{~mm}$. Credits: M. C. Thomas, Division of Plant Industry

\section{Paederinae}

Adults are 1.5->20 mm (not exceeding $19.5 \mathrm{~mm}$ in Florida) long, elongate, a few of them brightly colored, including metallic blue and green; they have long, curved and slender mandibles; the antennae have 11 articles and these are simple, or slightly broadened toward the apex, or all articles distal to the basal two are very slender (in Thinocharis); the tarsi have five articles. The anterior tarsi are greatly expanded in the tribe Pinophilini, the sclerites are fused in a ring around each abdominal segment in the subtribe Palaminina, the antennae are geniculate in the subtribe Cryptobiina. Characteristics uniting the species in Paederinae are very similar to those of the following subfamily, Staphylininae, but pupae are exarate and unsclerotized.

Paederinae inhabit various decaying plant materials. Adults of Paederus (which have normal anterior tarsi) and Palaminus (which have expanded anterior tarsi) climb on vegetation. Adults and larvae are predatory. Larvae as a rule seem to have only two instars whereas three is the usual number in Staphylininae. One species of Myrmecosaurus is associated with Solenopsis ants (Tschinkel 1992, Wojcik 1980). Larvae of only one genus (Astenus) are known to spin silken cocoons. Sixty-six species are so far reported from Florida (Abarbanell \& Ashe 1989; Watrous 1981), although there are more.

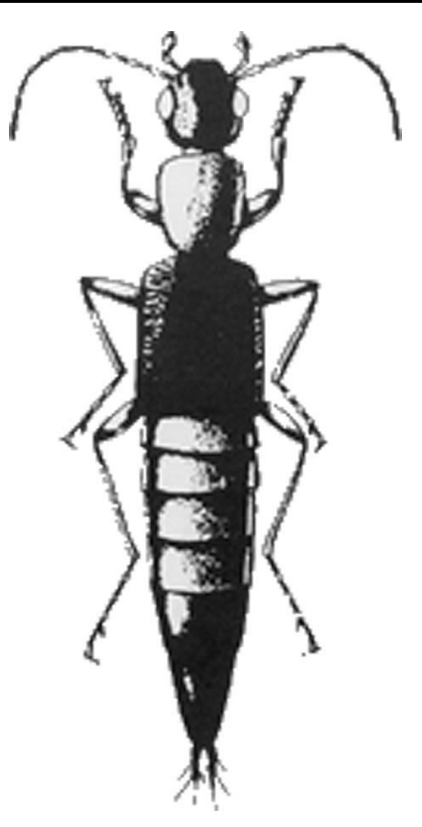

Figure 16. Paederus sp. (Paederinae) $6.7 \mathrm{~mm}$. Credits: M. C. Thomas, Division of Plant Industry 


\section{Staphyliniae}

Adults are 1.5-40 $\mathrm{mm}$ long (not exceeding about $20 \mathrm{~mm}$ in Florida), elongate, some of them brilliantly colored, including metallic blue, green, purple and red; they have long, curved and slender mandibles; in some species the eyes are large; the antennae have 11 articles and these are simple or broadened toward the apex; the tarsi in almost all genera have 5 articles. Included are members of the tribe Xantholinini in which the elytra overlap slightly, and members of the genus Atanygnathus in which the middle and posterior tarsi have only four articles. Larvae differ from those of all other subfamilies except Paederinae in having an articulated maxillary mala, and they differ from those in having a conical labial ligula (it tapers in Paederinae). Pupae differ from those of all other subfamilies in being obtect and sclerotized.

If any behavior of adult Staphylinidae has achieved notoriety among entomologists, it is the predatory behavior of large adults and larvae of such genera as Creophilus (Voris 1939, Kramer 1955), Erichsonius (Schmidt 1996), Neohypnus (Hu \& Frank 1995a), Ontholestes (Voris 1939), Neobisnius (Schmidt 1994b), Philonthus (Hu \& Frank 1998), and Platydracus (Voris 1939, Schmidt 1994a), because these are observed relatively easily. Adults and larvae occur in many habitats including forest leaf litter, decaying plant materials including fruit, fungi, carrion, dung, under bark of dead trees, and in washed-up brown algae (Fucales [called kelp or wrack]) on seashores (Frank et al. 1986). Ninety-six species so far are reported for Florida (Frank 1975, 1981, Smetana 1971, 1982, 1995), although there are more.

\section{Acknowledgments}

We are indebted to Dr J.M. Campbell, Mr. I. Steins, Mr. G. Sato, and Agriculture Canada for permission to use the figures of Peplomicrus sp. and Megalopinus rufipes, and to Dr E.R. Van Tassell for the figure of Trimiomelba dubia.

\section{Selected References}

Abarbanell NR, Ashe JS. 1989. Revision of the species of Pinophilus Gravenhorst (Coleoptera:

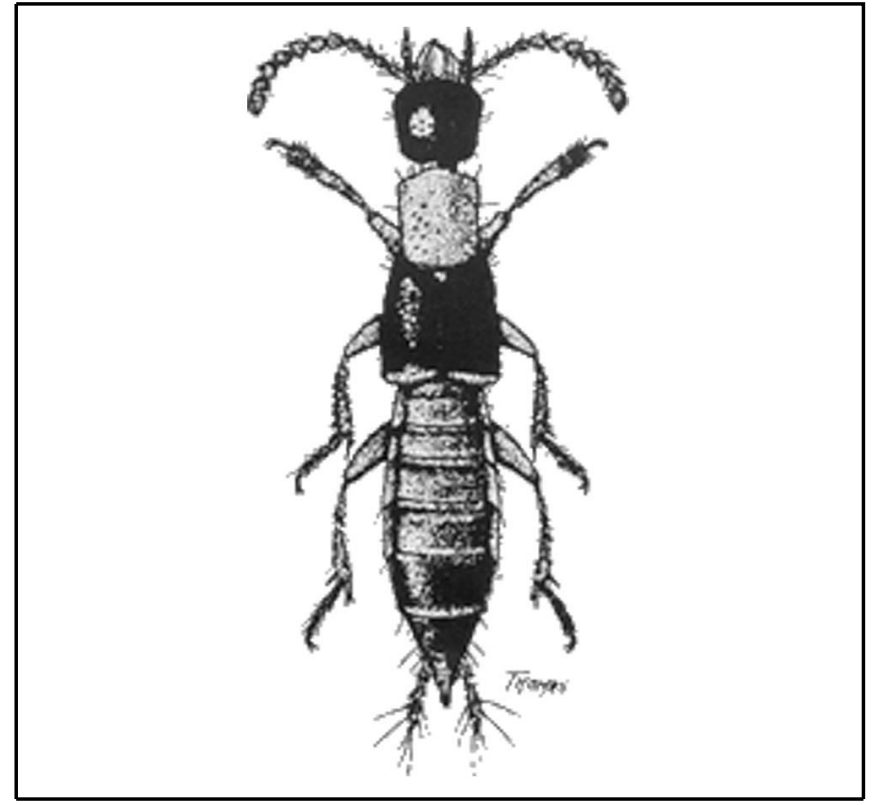

Figure 17. Neobisnius ludicrus (Erichson) (Staphylininae) $4.1 \mathrm{~mm}$. Credits: M. C. Thomas, Division of Plant Industry

Staphylinidae) of America north of Mexico. Fieldiana: Zoology (N.S.) 54: i-iii, 1-32.

Ashe JS. 1986. Phanerota cubensis and Phanerota brunnessa n.sp., with a key to the species of Phanerota occurring in Florida (Coleoptera: Staphylinidae). Florida Entomologist 69: 236-245.

Ashe JS. 1987. Egg chamber production, egg protection, and clutch size among fungivorous beetles of the genus Eumicrota Casey (Coleoptera: Staphylinidae) and their evolutionary implications. Zoological Journal of the Linnean Society 90: 255-273.

Bohác J. 1978. Description of the larva and pupa of Thoracophorus brevicristatus (Coleoptera, Staphylinidae). Acta Entomologica Bohemoslovaca 75: 394-399.

Campbell JM. 1968. A revision of the New World Micropeplinae (Coleoptera: Staphylinidae) with a rearrangement of the world species. Canadian Entomologist 100: 225-267.

Campbell JM. 1969. A revision of the New World Oxyporinae (Coleoptera: Staphylinidae). Canadian Entomologist 101: 225-268.

Campbell JM. 1975. A revision of the genera Coproporus and Cilea (Coleoptera: Staphylinidae) of 
America north of Mexico. Canadian Entomologist 107: 175- 216.

Campbell JM. 1976. A revision of the genus Sepedophilus (Coleoptera: Staphylinidae) of America north of Mexico. Memoirs of the Entomological Society of Canada 99: 1-89.

Campbell JM. 1979. A revision of the genus Tachyporus Gravenhorst (Coleoptera: Staphylinidae) of North and Central America. Memoirs of the Entomological Society of Canada 109: 1-195.

Campbell JM. 1991. A revision of the genera Mycetoporus Mannerheim and Ischnosoma Stephens (Coleoptera: Staphylinidae: Tachyporinae) of North and Central America. Memoirs of the Entomological Society of Canada 156: 1-169.

Campbell JM. 1993. A revision of the genera Bryoporus Kraatz and Bryophacis Reitter and two new related genera from America north of Mexico (Coleoptera: Staphylinidae: Tachyporinae). Memoirs of the Entomological Society of Canada 166: 1-85.

Chandler DS. 1997. A catalog of the Coleoptera of America north of Mexico. Family Pselaphidae. USDA Agriculture Handbook 529(31): i-ix, 1-118.

Chittenden FH. 1915. The violet rove-beetle (Apocellus sphaericollis Say). USDA Bulletin 264: $1-41$.

Frank JH. 1975. A revision of the New World species of the genus Erichsonius Fauvel (Coleoptera: Staphylinidae). Coleopterists Bulletin 29: 177-203.

Frank JH. 1979. A new species of Proteinus Latreille (Coleoptera: Staphylinidae) from Florida. Florida Entomologist 62: 329-340.

Frank JH. 1981. A revision of the New World species of the genus Neobisnius Ganglbauer (Coleoptera: Staphylinidae: Staphylininae). Occasional Papers of the Florida State Collection of Arthropods 1: i-viii, 1-60.

Frank JH. 1986. A preliminary checklist of the Staphylinidae (Coleoptera) of Florida. Florida Entomologist 69: 363-382. [Note: One of the pages of the checklist was placed by the publishing company in the wrong sequence -- see Florida Entomologist 69: 770 -- reprints, however, were paged correctly].

Frank JH. 1991. Staphylinidae, p. 341-352, in Stehr FW (ed.) Immature insects. Vol. 2. Dubuque, Iowa: Kendall-Hunt, xvi + 975 p.

Frank JH, Carlysle TC, Rey JR. 1986. Biogeography of the seashore Staphylinidae Cafius bistriatus and C. rufifrons (Insecta: Coleoptera). Florida Scientist 49: 148-161.

Frank JH, Thomas MC. 1981. Myrmedoniini (Coleoptera, Staphylinidae, Aleocharinae) associated with army ants (Hymenoptera, Formicidae, Ecitoninae) in Florida. Florida Entomologist 64: 138-146.

Frank JH, Thomas MC. 1984a. Cubanotyphlus largo, a new species of Leptotyphlinae (Coleoptera, Staphylinidae) from Florida. Canadian Entomologist 116: 1411- 1417.

Frank JH, Thomas MC. 1984b. Heterota plumbea and Coenonica puncticollis in Florida (Coleoptera: Staphylinidae). Florida Entomologist 64: 409-417.

Frank JH, Thomas MC. 1997. A new species of Charoxus (Coleoptera: Staphylinidae) from native figs (Ficus spp.) in Florida. Journal of the New York Entomological Society 104 (996"): 409-417.

Frank, JH, and Thomas MC. (September 1999). "Rove beetles of the world. UF/IFAS Featured Creatures. EENY-114 (http://edis.ifas.ufl.edu/IN271). (October 1999).

Génier F. 1989. A revision of the genus Hoplandria Kraatz of America north of Mexico (Coleoptera: Staphylinidae, Aleocharinae). Memoirs of the Entomological Society of Canada 150: 1-59.

Herman LH. 1986. Revision of Bledius. Part IV. Classification of species groups, phylogeny, natural history, and catalogue (Coleoptera, Staphylinidae, Oxytelinae). Bulletin of the American Museum of Natural History 184: 1-368.

Hoebeke ER. 1985. A revision of the rove beetle tribe Falagriini of America north of Mexico 
(Coleoptera: Staphylinidae: Aleocharinae). Journal of the New York Entomological Society 93: 913-1018.

Hu GY, Frank JH. 1995a. New distributional records for Platystethus (Coleoptera: Staphylinidae: Oxytelinae) with notes on the biology of $P$. americanus. Florida Entomologist 78: 137-144.

Hu GY, Frank JH. 1995b. Biology of Neohypnus pusillus (Sachse) and its predation on immature horn flies in the laboratory. Coleopterists Bulletin 49: 43-52.

Hu GY, Frank JH. 1998. Predation on the horn fly (Diptera: Muscidae) by five species of Philonthus (Coleoptera: Staphylinidae). Environmental Entomology 26 (997"): 1240-1246.

Klimaszewski J, Frank JH, Peck SB. 1990. Two new species and a key to the adults of Aleochara of Florida (Coleoptera: Staphylinidae). Florida Entomologist 73: 177-185.

Klimaszewski J, Peck SB. 1986. A review of the cavernicolous Staphylinidae (Coleoptera) of eastern North America: Part I. Aleocharinae. Quaestiones Entomologicae 22: 511-513.

Kramer S. 1955. Notes and observations on the biology and rearing of Creophilus maxillosus (L.) (Coleoptera: Staphylinidae). Annals of the Entomological Society of America 48: 375-380.

Lawrence JF, Newton A. 1995. Families and subfamilies of Coleoptera (with selected genera, notes, references and data of family group-names), $\mathrm{p}$. 779-1006, in Pakaluk J, Slipiski SA (eds.) Biology, phylogeny and classification of Coleoptera. Warsaw: Muzeum i Instytut PAN.

Leschen RAB. 1988. Natural history and immatures of Scaphisoma impunctatum (Coleoptera: Scaphidiidae). Entomological News 99: 225-232.

Leschen RAB, Allen RT. 1988. Immature stages, life histories and feeding mechanisms of three Oxyporus spp. (Coleoptera: Staphylinidae: Oxyporinae). Coleopterists Bulletin 42: 321-333.
Lundgren RW. 1998. Family Staphylinidae, p. 37-54, in Peck SB, Thomas MC. A distributional checklist of the beetles (Coleoptera) of Florida. Arthropods of Florida and Neighboring Land Areas 16: i-viii, 1-180.

Newton AF. 1988. Fooled by flatness: subfamily shifts in subcortical Staphylinidae (Coleoptera). Coleopterists Bulletin 42: 381-384.

Newton AF. 1991. Micropeplidae, Dasyceridae, Scaphidiidae, p. 334-338, and Pselaphidae, p. 353-355, in Stehr FW (ed.) Immature Insects. Vol. 2. Dubuque, Iowa: Kendall- Hunt.

Schmidt DA. 1994a. Notes on the biology and a description of the egg, third instar larva and pupa of Platydracus tomentosus (Gravenhorst) (Coleoptera: Staphylinidae). Coleopterists Bulletin 48: 310-318.

Schmidt DA. 1994b. Notes on the biology and a description of the egg, third instar larva and pupa of Neobisnius sobrinus (Coleoptera: Staphylinidae). Transactions of the Nebraska Academy of Sciences 21: 55-61.

Schmidt DA. 1996. Description of the immatures of Erichsonius alumnus Frank and E. pusio (Horn) (Coleoptera: Staphylinidae). Coleopterists Bulletin 50: 205- 215.

Seevers CH. 1978. A generic and tribal revision of the North American Aleocharinae (Coleoptera: Staphylinidae). Fieldiana: Zoology 71: i-vi, 1-289.

Smetana A. 1971. Revision of the tribe Quediini of America north of Mexico (Coleoptera: Staphylinidae). Memoirs of the Entomological Society of Canada 79: i-vi, 1-303.

Smetana A. 1982. Revision of the subfamily Xantholininae of America north of Mexico (Coleoptera: Staphylinidae). Memoirs of the Entomological Society of Canada 120: i-iv, 1- 389.

Smetana A. 1995. Rove beetles of the subtribe Philonthina of America north of Mexico (Coleoptera: Staphylinidae). Classification, phylogeny and taxonomic revision. Memoirs on Entomology, International 3: i-x, 1-946. 
Tschinkel WR. 1992. Brood raiding in the fire ant, Solenopsis invicta (Hymenoptera: Formicidae): laboratory and field observations. Annals of the Entomological Society of America 85: 638-646.

Voris R. 1939. The immature stages of the genera Ontholestes, Creophilus and Staphylinus Staphylinidae (Coleoptera). Annals of the Entomological Society of America 32: 288-303.

Watrous LE. 1981. Lathrobium (Tetartopeus): Natural history, phylogeny and revision of the Nearctic species (Coleoptera: Staphylinidae). Systematic Entomology 5: 303-338.

Weinreich E. 1968. Über den Klebfangapparat der Imagines von Stenus Latr. (Coleopt., Staphylinidae) mit einem Beitrag zur Kenntnis der Jugendstadien dieser Gattung. Zeitschrift für Morphologie der Tiere 62: 162-210.

White RE. 1983. A field guide to the beetles of North America. (Peterson Field Guide Series). Boston, MA: Houghton Mifflin, xii + 368 p.

Wojcik DP. 1980. Fire ant myrmecophiles: behavior of Myrmecosaurus ferrugineus Bruch (Coleoptera: Staphylinidae) with comments on its abundance. Sociobiology 5: 63-68. 